\title{
GAMBARAN PENGETAHUAN DAN SIKAP IBU HAMIL TENTANG ASI EKSKLUSIF DI POLIKLINIK OBSTETRI BLU RSUP PROF. DR. R. D. KANDOU MANADO
}

\author{
Fauzia Tamara Rauf \\ dr. Rudy A. Lengkong, SpOG(K) \\ dr. Maya Mewengkang, SpOG
}

\author{
Bagian Obstetri Ginekologi BLU RSUP Prof. Dr. R. D. Kandou Manado \\ tamara.rauf@yahoo.co.id
}

\begin{abstract}
Abstrak: Air susu ibu (ASI) merupakan makanan terbaik bagi bayi karena mengandung zat gizi yang ideal untuk bayi, terutama pada umur 0 sampai 6 bulan. ASI Eksklusif adalah ASI yang diberikan kepada bayi sejak dilahirkan selama enam bulan, tanpa menambahkan dan/atau mengganti dengan makanan atau minuman lain. Hasil riset kesehatan dasar tahun 2010 bayi yang diberikan ASI eksklusif sampai 6 bulan hanya 15,3\%. Provinsi Sulawesi Utara pada tahun 2010 cakupan ASI eksklusifnya hanya sebesar 22,61\%, yang masih terpaut jauh dari target nasional yaitu $80 \%$. Tujuan dari penelitian ini untuk mengetahui gambaran pengetahuan dan sikap ibu hamil di Poliklinik Obstetri BLU RSUP Prof. DR. R.D. Kandou Manado tentang pentingnya ASI eksklusif. Penelitian ini bersifat deskriptif dengan menggunakan pendekatan cross sectional. Sampel penelitian sebesar 50 sampel ibu hamil. Instrumen yang digunakan adalah kuesioner. Analisis data dilakukan secara univariat. Hasil penelitian menunjukkan ibu dengan pengetahuan baik tentang ASI eksklusif ada sebanyak 38\%, pengetahuan tidak baik ada 62\%. sikap baik tentang ASI eksklusif sebanyak $46 \%$ dan sikap yang tidak baik 54\%. Terdapat kelompok karakteristik yang paling banyak berpengetahuan baik dan berpengetahuan tidak baik terdapat pada kelompok yang sama (>30tahun, SLTA, Tidak bekerja). Sedangkan kelompok karakteristik yang paling banyak memiliki sikap baik dan sikap tidak baik terdapat pada kelompok yang sama juga (>30tahun, SLTA, Tidak bekerja).

Kesimpulan: didapatkan paling banyak yang berpengetahuan tidak baik, dan sikap tidak baik. Namun, tidak dapat dilihat adanya pengaruh yang signifikan antara karakteristik umur, pendidikan, dan pekerjaan terhadap pengetahuan dan sikap ibu hamil tentang ASI eksklusif pada penelitian ini oleh karena beberapa faktor.
\end{abstract}

Kata kunci: Pengetahuan, Sikap, ASI Eksklusif

Abstract: Breast milk is the best meal for babies because it contains ideal nutritions for babies, espesially for 0 to 6 months babies. Exclusive breast milk is the one the mothers give since they was born until 6 months old, without adding or replacing it with any other meals or drinks. The result of 2010 basic health study states that there were 15,3\% babies given exclusive breast milk, while $22,61 \%$ of that number was in north celebes, which were far away from national target, $80 \%$. The aim of this study is to describe the knowledge and attitude of pregnant women in obsgyn clinic in Kandou Hospital about how important exclusive breast milk is. This is a descriptive study using cross sectional approachment. This study has 50 samples of pregnant women, using quittionaire as instrument. Data analysis is done by univariet. Result shows $38 \%$ of pregnant women have good knowledge about exclusive breast milk and $62 \%$ have bad knowledge. Good attitude about exclusive breast milk reaches $46 \%$ while $54 \%$ has bad attitude. This study identified the group with good and bad knowledge were in the same group ( $<30$ years old, senior high school, unemployee). At 
the same time, group with most number of good and bad attitude were also in the same group ( $<30$ years old, senior high school, unemployee).

Conclusion: This study results that bad knowledge and attitude have the highest percentage. However, it is unable to see the significant effect between age, education and occupation characteristic with the knowledge and attitude of pregnant women about exclusive breast milk in this study because of some factors.

Keyword: Knowledge, Attitude, Exclusive Breast Milk.

\section{Pendahuluan}

Menyusui adalah komponen utama dalam kehidupan anak. ASI adalah makanan pertama yang alami untuk bayi. ASI menyediakan semua energi dan nutrisi yang dibutuhkan untuk bayi. ${ }^{1}$

Pemberian ASI Eksklusif kepada bayi umur 0-6 bulan tanpa memberikan/mengganti dengan makanan atau minuman lain sangat dianjurkan dan memberikan makanan pendamping ASI secara benar setelah itu sampai bayi/anak umur berumur 2 tahun. ${ }^{2}$

Rekomendasi WHO/UNICEF pada pertemuan tahun 1979 di Geneva tentang makanan bayi dan anak antara lain berisi: "Menyusukan merupakan bagian terpadu dari proses reproduksi yang memberikan makanan bayi secara ideal dan alamiah serta merupakan dasar biologik dan psikologik yang dibutuhkan untuk pertumbuhan. Memberikan susu formula sebagai tambahan dengan dalih apapun pada bayi baru lahir harus dihindarkan"3

Secara nasional cakupan pemberian ASI eksklusif di Indonesia berfluktuasi selama 3 tahun terakhir. Cakupan pemberian ASI eksklusif pada bayi 0-5 bulan turun dari 62,2\% tahun 2007 menjadi 56,2\% pada tahun 2008, namun meningkat lagi pada tahun 2009 menjadi $61,3 \%$. Sedangkan cakupan pemberian ASI eksklusif pada bayi sampai 6 bulan turun dari 28,6\% pada tahun 2007 menjadi 24,3\% pada tahun 2008 dan naik lagi menjadi 34,3\% pada tahun $2009 .^{4}$

Hasil riset kesehatan dasar tahun 2010 bayi yang diberikan ASI eksklusif sampai 6 bulan hanya 15,3\%. Provinsi Sulawesi Utara pada tahun 2010 cakupan ASI eksklusifnya hanya sebesar 22,61\%, yang masih terpaut jauh daritarget nasional yaitu 80\% dan untuk data ASI eksklusif di Kota Manado sendiri yang merupakan Ibu Kota dari Provinsi Sulawesi Utara cakupan ASI eksklusifnya berada pada urutan kedua terendah yaitu 5,53\%. Hal ini disebabkan kesadaran masyarakat dalam mendorong peningkatan pemberian ASI masih relatif rendah. ${ }^{5}$

\section{Metode Penelitian}

Penelitian ini bersifat deskriptif cross-sectional yang dilakukan di Poliklinik Obstetri BLU RSUP Prof. Kandou yang dilakukan dari bulan November 2013 hingga Desember 2013. Populasi dari penelitian ini adalah semua Ibu Hamil di Polikliknik Obstetri BLU RSUP Prof. Dr. R. D. Kandou dengan besar sampel sebanyak 50 ibu hamil yang memenuhi kriteria inklusi. Dimana kriteria inklusi ini adalah Ibu hamil, tercatat sebagai pasien di Poliklinik Obstetri BLU RSUP Prof. Dr. R. D. Kandou dan bersedia sebagai subjek penelitian dengan mengisi lembaran kuesioner. Sedangkan kriteria eksklusi penelitiaan ini adalah Bukan ibu hamil, tidak bersedia sebagai subjek penelitian, pasien yang tidak hadir saat pengambilan sampel. Data hasil penelitian diperoleh dengan mengumpulkan data primer yang langsung diambil di lapangan dengan menggunakan kuesioner dimana variabel yang akan diteliti adalah umur, pekerjaan, pendidikan, sikap, dan pengetahuan. Hasil penelitian diolah dengan sistem komputerisasi dengan menggunakan program SPSS (Statistical Package for the Social Sciences) versi 2.0 . 


\section{Hasil Penelitian}

Tabel 1 menunjukkan umur ibu paling banyak yaitu pada kategori $>30$ tahun, sedangkan paling sedikit juga pada kategori $>30$ tahun. Untuk pendidikan terakhir ibu paling banyak yaitu tamatan SLTA, sedangkan paling sedikit juga ada pada tamatan SLTA. Untuk pekerjaan ibu paling banyak yaitu ibu yang tidak bekerja sedangkan yang paling sedikit juga pada ibu tidak bekerja.

Tabel 1. Distribusi Frekuensi Responden Berdasarkan Karakteristik Responden

\begin{tabular}{llcc}
\hline & Karakteristik Responden & Jumlah & Persentasi (\%) \\
\hline Usia Ibu & $<18$ tahun & 1 & $2 \%$ \\
& 18-25 tahun & 16 & $32 \%$ \\
& 26-30 tahun & 10 & $20 \%$ \\
& $>30$ tahun & 23 & $46 \%$ \\
\hline Pendidikan Terakhir & SD & 2 & $4 \%$ \\
& SLTP & 17 & $34 \%$ \\
& SLTA & 24 & $48 \%$ \\
& Perguruan Tinggi & 7 & $14 \%$ \\
\hline Pekerjaan & Bekerja & 8 & $16 \%$ \\
& Tidak Bekerja & 42 & $84 \%$ \\
\hline
\end{tabular}

Tabel 2 menunjukkan ibu dengan pengetahuan baik tentang ASI eksklusif ada sebanyak 19 orang (38\%), pengetahuan tidak baik 31 orang (62\%).

Tabel 2. Gambaran Pengetahuan Ibu Hamil Tentang ASI Eksklusif

\begin{tabular}{|c|c|c|c|c|}
\hline \multicolumn{3}{|c|}{ Pengetahuan } & \multicolumn{2}{|c|}{ Total } \\
\hline & & Tidak Baik & & \\
\hline $\mathrm{n}$ & $\%$ & $\%$ & $\mathrm{n}$ & $\%$ \\
\hline 19 & 38 & $31 \quad 62$ & 50 & 100 \\
\hline
\end{tabular}

Tabel 3 Menunjukkan ibu yang memiliki sikap baik tentang ASI eksklusif sebanyak 23 orang (46\%) dan sikap yang tidak baik 27 orang (54\%).

Tabel 3. Gambaran Sikap Ibu Hamil Tentang ASI Eksklusif

\begin{tabular}{|c|c|c|c|}
\hline \multicolumn{2}{|c|}{ Sikap } & \multicolumn{2}{|c|}{ Total } \\
\hline Baik & Tidak Baik & & \\
\hline$\%$ & $\%$ & $\mathrm{n}$ & $\%$ \\
\hline $23 \quad 46$ & 27 & 50 & 100 \\
\hline
\end{tabular}

Tabel 4 menunjukkan pengetahuan baik dan pengetahuan tidak baik tentang ASI eksklusif menurut karakteristik usia ibu. Dimana untuk karateristik umur, ibu yang memiliki pengetahuan baik paling banyak pada kelompok umur $>30$ tahun, yaitu 11 0rang (22\%) dan yang memiliki pengetahuan tidak baik paling banyak juga terdapat pada kelompok umur $>30$ tahun, yaitu 12 orang (24\%). Untuk karakteristik pendidikan terakhir, ibu yang memiliki pengetahuan baik paling banyak pada tamatan SLTA, yaitu 9 orang (18\%) sedangkan ibu yang memilki pengetahuan tidak baik paling banyak juga pada tamatan SLTA, yaitu 15 orang (30\%). Untuk karakteristik pekerjaan yang memiliki pengetahuan baik paling banyak pada status tidak bekerja, yaitu 13 orang (26\%) dan yang memilki pengetahuan tidak baik juga pada status tidak bekerja, yaitu 29 orang (58\%). 
Tabel 4. Frekuensi Tingkat Pengetahuan Berdasarkan Karakteristik Responden

\begin{tabular}{|c|c|c|c|c|c|c|}
\hline \multirow[t]{3}{*}{ Karekteristik Ibu } & \multicolumn{4}{|c|}{ Pengetahuan } & \\
\hline & \multicolumn{2}{|c|}{ Baik } & \multicolumn{2}{|c|}{ Tidak Baik } & \multicolumn{2}{|c|}{ Total } \\
\hline & $\mathbf{n}$ & $\%$ & $\mathbf{n}$ & $\%$ & $\mathbf{n}$ & $\%$ \\
\hline \multicolumn{7}{|l|}{ Usia Ibu } \\
\hline$<18$ tahun & 0 & $0 \%$ & 1 & $2 \%$ & 1 & $2 \%$ \\
\hline 18-25 tahun & 2 & $4 \%$ & 14 & $28 \%$ & 16 & $32 \%$ \\
\hline 26-30 tahun & 6 & $12 \%$ & 4 & $8 \%$ & 10 & $20 \%$ \\
\hline$>30$ tahun & 11 & $22 \%$ & 12 & $24 \%$ & 23 & $46 \%$ \\
\hline \multicolumn{7}{|l|}{ Pendidikan Terakhir } \\
\hline SD & 0 & $0 \%$ & 2 & $4 \%$ & 2 & $4 \%$ \\
\hline SLTP & 4 & $8 \%$ & 13 & $26 \%$ & 17 & $34 \%$ \\
\hline SLTA & 9 & $18 \%$ & 15 & $30 \%$ & 24 & $48 \%$ \\
\hline Perguruan Tinggi & 6 & $12 \%$ & 1 & $2 \%$ & 7 & $14 \%$ \\
\hline \multicolumn{7}{|l|}{ Pekerjaan } \\
\hline Bekerja & 6 & $12 \%$ & 2 & $4 \%$ & 8 & $16 \%$ \\
\hline Tidak Bekerja & 13 & $26 \%$ & 29 & $58 \%$ & 42 & $84 \%$ \\
\hline
\end{tabular}

Tabel 5 menunjukkan sikap baik dan tidak baik tentang ASI Eksklusif berdasarkan karakteristik ibu. untuk karateristik umur, ibu yang memiliki sikap baik paling banyak pada kelompok umur $>30$ tahun, yaitu 13 orang (26\%) dan yang memiliki sikap tidak baik paling banyak juga terdapat pada kelompok umur >30 tahun, yaitu 10 orang (20\%). Untuk karakteristik pendidikan terakhir, ibu yang memiliki sikap baik paling banyak pada tamatan SLTA, yaitu 12 orang (24\%) sedangkan ibu yang memilki sikap tidak baik paling banyak juga pada tamatan SLTA, yaitu 12 orang (24\%). Untuk karakteristik pekerjaan yang memiliki sikap baik paling banyak pada status tidak bekerja, yaitu 16 orang (32\%) dan yang memilki sikap tidak baik juga pada status tidak bekerja, yaitu 26 orang (52\%).

Tabel 5. Frekuensi Sikap Baik dan Tidak Baik Berdasarkan Karakteristik Responden

\begin{tabular}{lcccccc}
\hline Karekteristik Ibu & \multicolumn{9}{c}{ Sikap } & \multicolumn{2}{c}{ Total } \\
& \multicolumn{1}{c}{ Baik } & \multicolumn{2}{c}{ Tidak Baik } & & \\
& $\mathbf{n}$ & $\mathbf{\%}$ & $\mathbf{n}$ & $\mathbf{\%}$ & $\mathbf{n}$ & $\mathbf{\%}$ \\
\hline Usia Ibu & & & & & & \\
$<18$ tahun & 0 & $0 \%$ & 1 & $2 \%$ & 1 & $2 \%$ \\
18-25 tahun & 2 & $4 \%$ & 14 & $28 \%$ & 16 & $32 \%$ \\
26-30 tahun & 8 & $16 \%$ & 2 & $4 \%$ & 10 & $20 \%$ \\
$>30$ tahun & 13 & $26 \%$ & 10 & $20 \%$ & 23 & $46 \%$ \\
\hline Pendidikan Terakhir & & & & & & \\
SD & 0 & $0 \%$ & 2 & $4 \%$ & 2 & $4 \%$ \\
SLTP & 4 & $8 \%$ & 13 & $26 \%$ & 17 & $34 \%$ \\
SLTA & 12 & $24 \%$ & 12 & $24 \%$ & 24 & $48 \%$ \\
Perguruan Tinggi & 7 & $14 \%$ & 0 & $0 \%$ & 7 & $14 \%$ \\
\hline Pekerjaan & & & & & & \\
Bekerja & 7 & $14 \%$ & 1 & $2 \%$ & 8 & $16 \%$ \\
Tidak Bekerja & 16 & $32 \%$ & 26 & $52 \%$ & 42 & $84 \%$ \\
\hline
\end{tabular}

Pembahasan

Tabel 1 menunjukan distribusi frekuensi responden berdasarkan karakteristik 
responden subjek penelitian, yang mana untuk karakteristik usia, paling banyak responden dengan usia $>30$ tahun (46\%) dan untuk karakteristik pekerjaan paling banyak responden dengan status tidak bekerja (84\%), hal ini hampir sama dengan penelitian sebelumnya yang telah dilakukan di wilayah Puskesmas Pancoran Mas Depok tahun 2008 dengan jumlah responden $>30$ tahun sebesar $41,4 \%$ dan responden yang tidak bekerja sebesar $86,7 \%{ }^{6}$ Sedangkan untuk karateristik pendidikan paling banyak responden merupakan tamatan SLTA (48\%), hal ini menunjukan mayoritas ibu hamil terutama yang berkunjung ke Poliklinik Obstetri BLU RSUP Prof. Kandou adalah tamatan SLTA.

Tabel 2 dan tabel 3 menunjukkan gambaran pengetahuan dan sikap responden tentang ASI Eksklusif. Dari 50 responden didapatkan lebih banyak responden yang berpengetahuan tidak baik yaitu sebesar 31 orang (62\%) dan untuk sikap sendiri di dapatkan paling banyak yang memiliki sikap tidak baik yaitu 27 orang (54\%). Oleh karena kurangnya tingkat pengetahuan tentang ASI eksklusif dan sikap yang tidak mendukung terhadap ASI eksklusif, maka tidak heran melihat adanya insiden penurunan pemberian ASI eksklusif yang dimana di Sulawesi Utara sendiri tingkat pemberian ASI eksklusif hanya sebesar 22.61\%, yang masih terpaut jauh dari target nasional yaitu $80 \% .^{5}$

Frekuensi tingkat pengetahuan berdasarkan karakteristik responden dijelaskan pada tabel 4. Dalam karakteristik usia ibu, terlihat pengetahuan yang baik paling banyak ada pada usia >30 tahun, yaitu dengan jumlah 11 orang (22\%). Data ini sesuai dengan teori yang menjelaskan semakin cukup umur maka tingkat kematangan dan kekuatan seseorang akan lebih matang dalam berfikir. ${ }^{7}$ Sedangkan untuk karakteristik pendidikan terakhir terdapat paling banyak pada SLTA, yaitu 9 orang (18\%). Hal ini sesuai dengan teori yang mengatakan bahwa faktor yang mempengaruhi pengetahuan antara lain tingkat pendidikan, yang dimana semakin tinggi tingkat pendidikan seseorang, maka dia akan lebih mudah menerima dan menyelesaikan hal-hal baru. ${ }^{8}$ Dan yang terakhir untuk karakteristik pekerjaan paling banyak dengan status tidak bekerja, yaitu 13 orang (26\%). Untuk hubungan antara pekerjaan dengan pengetahuan belum didapat teori yang jelas. Namun diasumsikan oleh karena ibu-ibu yang tidak bekerja memiliki lebih banyak waktu luang untuk mencari informasi terutama terkait dengan ASI eksklusif. Sedangkan untuk pengetahuan tidak baik, paling banyak juga terdapat pada umur $>30$ tahun sebanyak 12 orang (24\%), SLTA sebanyak 15 orang (30\%), dan status tidak bekerja sebanyak 29 orang (58\%). Hal ini memang bertentangan dengan teori bahwa faktor yang mempengaruhi pengetahuan itu bukan hanya usia, pendidikan dan pekerjaan, namun bisa juga seperti banyak atau kurangnya informasi yang diterima, atau bisa juga kebudayaan dan lingkungan. ${ }^{9}$

Tabel 5 menunjukkan frekuensi sikap baik dan tidak baik berdasarkan karakteristik responden. . Untuk karakteristik usia ibu sikap baik paling banyak pada usia $>30$ tahun, yaitu sebesar 13 orang (26\%). Dan untuk pendidikan terakhir paling banyak pada SLTA dengan jumlah 12 orang (24\%). Hasil penelitian ini sama dengan pada tabel 6 yang dimana di tunjukan yang berpengetahuan baik ada pada kelompok usia $>30$ tahun dan pada tamatan SLTA, hal ini bisa jadi berkaitan dengan teori yang menyatakan bahwa tingkat pengetahuan seseorang akan mempegaruhi sikap dalam kehidupan sehari-hari. ${ }^{10}$ Oleh karenanya kategori responden yang paling banyak berpengetahuan baik sama dengan kategori responden yang paling banyak memiliki sikap baik (>30tahun, SLTA). Untuk karakteristik pekerjaan, paling banyak responden yang memiliki sikap baik berstatus tidak bekerja dengan jumlah 13 orang (26\%). Hal ini diasumsikan karena kesempatan yang dimiliki oleh ibu lebih banyak, sehingga ibu akan memiliki kesiapan dan kesediaan untuk memberikan ASI pada bayinya nanti. Sedangkan untuk sikap tidak baik paling banyak juga terdapat pada yang $>30$ tahun sebesar 10 orang (20\%), SLTA sebesar 12 orang (24\%), dan status tidak bekerja sebesar 26 orang (52\%). Hal ini dapat dihubungkan oleh pengetahuan tidak baik yang juga terdapat pada kelompok $>30$ tahun, SLTA, dan tidak bekerja, yang dapat dikarenakan oleh faktor- 
faktor lain yang dapat mempengaruhi sikap seperti pengalaman pribadi dan media massa. ${ }^{11}$ Contoh; pengalaman pribadi tidak memberikan ASI eksklusif pada anak sebelumnya dan media massa yang sering mempromosikan susu formula, sehingga bisa mempengaruhi pola pikir ibu.

Akan tetapi, dalam penelitian ini tidak juga dapat menunjukkan secara signifikan bahwa tingginya tingkat pendidikan terakhir, usia yang semakin matang, dan status bekerja atau tidak bekerja akan menjamin sikap positif dan pengetahuan yang baik terhadap ASI eksklusif, oleh karena jumlah responden antar kelompok di pendidikan terakhir, kelompok di usia, dan kelompok di status pekerjaan pada penelitian ini jumlahnya tidak seimbang.

\section{Kesimpulan}

Ibu yang berpengetahuan tidak baik 31 orang (62\%), yang memiliki sikap tidak baik 27 orang (54\%). , kelompok yang paling banyak berpengetahuan tidak baik ada pada kelompok umur $>30$ tahun, yaitu sebesar 12 orang (24\%), kelompok tamatan SLTA, yaitu sebesar 15 orang (30\%), dan kelompok dengan status tidak bekerja, yaitu sebesar 29 orang (58\%). Responden yang paling banyak memliki sikap tidak baik juga ada pada kelompok umur $>30$ tahun, dengan jumlah 10 orang (20\%), kelompok tamatan SLTA sebanyak12 orang (24\%), dan kelompok dengan status tidak bekerja, yaitu 26 orang (52\%).

\section{Saran}

Perlu ditingkatkan lagi usaha dalam meningkatkan pengetahuan dan sikap yang baik terhadap ASI eksklusif untuk meningkatkan status gizi yang lebih baik pada anak, seperti dengan meningkatkan kegiatan sosialisasi mengenai pentingnya ASI eksklusif. Serta perlu dilakukan penelitian-penelitian lebih lanjut lagi terkait ASI eksklusif dengan jumlah sampel lebih banyak dan jumlah sampel di masing-masing pengelompokkan karakteristik sama, agar dapat diidentifikasi lebih jelas faktor penyebab rendahnya pengetahuan dan sikap yang tidak baik terhadap ASI eksklusif sehingga dapat dibangun strategi-strategi untuk meningkatkan kembali pengetahuan dan sikap ibu yang baik tentang ASI eksklusif.

\section{Daftar Pustaka}

1. Afrose L, Banu B, Ahmad KR, Khanom K. Factor Associated With Knowledge About Breastfeeding Among Female Garment Workers In Dhaka City. WHO South-East Asia Journal of Public Health. 2012;1:249.

2. Sartono A, Utaminingrum H. Hubungan Pengetahuan Ibu, Pendidikan Ibu dan Dukungan Suami Dengan Praktek Pemberian ASI Eksklusif. Jurnal Gizi UNISMUS. 2012;1:2.

3. Wiknjosastro H, saifuddin A, Rachimhadhi T. Ilmu Kebidanan. Edisi ke-3. Jakarta: Yayasan Bina Pustaka Sarwono Prawirohardjo; 2005.

4. Rahmadhani Eka P, Lubis G, Edison. Hubungan Pemberian ASI Eksklusif Dengan Angka Kejadian Diare Akut Pada Bayi Usia 0-1 Tahun Di Puskesmas Kuranji Kota Padang. Jurnal Kesehatan Andalas. 2013;2:63.

5. Wenas W, Malonda NSH, Bolang ASL, Kapantow NH. Hubungan Antara Pengetahuan Dan Sikap Ibu Menyusui Dengan Pemberian Air Susu Ibu Eksklusif Di Wilayah Kerja Puskesmas Tompaso Kecamatan Tompaso. Diunduh dari: http://fkm.unsrat.ac.id/wp-content/uploads/2012/10/Winly-Wenas.pdf. $\quad$ Diakses 17 September 2013. 
6. Novita D. Hubungan Karakteristik Ibu Dengan Pemberian ASI Eksklusif. 2008. Diunduh dari: $\quad$ lontar.ui.ac.id/file?file=digital/123429-S-5452-Hubungan\%20karakteristikAnalisis.pdf. Diakses 17 Sept 2013.

7. Tanjung S, Tristanti I. Hubungan Tingkat Pendidikan Dengan Pengetahuan Tentang ASI Eksklusif Pada Ibu Menyusui Bayi (0-6 bulan) Di RB Bunda Jaten Karanganyar. EJurnal Maternal. 2011;5:40.

8. Lestari D, Zuraida R, Larasati TA. Hubungan Tingkat Pengetahuan Ibu Tentang ASI dan Pekerjaan Ibu Dengan Pemberian ASI Eksklusif di Kelurahan Fajar Bulan. Medical Jurnal of Lampung. 2013;2:93.

9. Octaviani CVA. Tingkat Pengetahuan Ibu Nifas Tentang Infeksi Luka Perineum Di RSU Assalam Gemolong Sragen. [skripsi-2012]

10. Kencana RB. Hubungan Tingkat Pengetahuan Remaja Tentang Kesehatan Reproduksi Dengan Sikap Terhadap Seks Pra Nikah. [skripsi-2011]

11. Nurdono DA. Gambaran Sikap Ibu Terhadap Masa Pre-menopouse Pada ibu-ibu. Jurnal Online Psikologi UMM. 2013;291-292. 